\title{
Using Inductive Instruction Into Teaching Topic "Primitive and Integral” For High School Students: The Survey of Mathematics Teachers in Vietnam
}

\author{
Nguyen Phu Loc ${ }^{1}$, Nguyen Huynh Thanh Tam ${ }^{2}$ \\ ${ }^{1}$ School of Education, Can Tho University, Vietnam \\ ${ }^{2}$ Lap Vo II High School, Dong Thap Province, Vietnam
}

\begin{abstract}
The inductive instruction is an active teaching method. By this method, the teacher can offer opportunities for students to observe, analyze, predict, generalize from some particular instances. The results of the survey showed that most teachers of mathematics teachers have recognized the strong points of this method; however, in teaching the topic "Primitive and Integral" of Calculus 12 in Vietnam, they have not been preferred to apply inductive instruction into their job.
\end{abstract}

Keywords: Primitive, integral, inductive instruction, calculus teaching, mathematics education.

\section{INTRODUCTION}

In the previous study (see [3]), we applied inductive instruction into teaching how to solve exercises of topic " Integration by Parts" - Calculus 12 [2] - with the process of teaching based on the inductive instruction; this process consists of 4 phases as follows (see Table 1):

Phase 1: Give an exercise of the above types of problem to students and ask them for creating analogous exercises.

Phase 2: Choose one of the exercises which were created by the students. The students work in group of four to find out strategies to apply "method of integration by parts" for solving the exercise chosen, and choose the best strategy.

Phase 3: Ask students for presenting the solution of the exercise according to the strategy which their group has just chosen in the blackboard

Phase 4: Ask students for generalizing the exercise with the corresponding solving strategy.

Table 1: The Objectives and students' activities in each phase of the experimental teaching

\begin{tabular}{|l|l|l|}
\hline Phase & Objective & Activity of students \\
\hline 1 & $\begin{array}{l}\text { Help Students identify features of a sample } \\
\text { exercise }\end{array}$ & $\begin{array}{l}\text { Observe and give some similar exercises } \\
\text { Individually }\end{array}$ \\
\hline 2 & $\begin{array}{l}\text { Help students find out how to apply } \\
\text { method of integration by parts to solve one } \\
\text { exercise suggested in Phase 1 }\end{array}$ & $\begin{array}{l}\text { Work in group to find out strategies for } \\
\text { applying method of integration in parts to } \\
\text { solve the exercise and choose the best strategy }\end{array}$ \\
\hline 3 & $\begin{array}{l}\text { Identify students ability to apply } \\
\text { method of integration by parts to solve the } \\
\text { chosen exercise }\end{array}$ & $\begin{array}{l}\text { Present the solution of the chosen exercise } \\
\text { Help students generalize the exercise }\end{array}$ \\
\hline
\end{tabular}

The results showed that students were active in process of learning and they could discover new knowledge; from this and basing on the content of textbook "Giải tích 12" (Calculus 12) [2] for 12 $2^{\text {th }}$ grade students in Vietnam, we recognize that inductive instruction can be applied the topic "Primitive and Integral". The question is that teachers regularly used this approach to their teaching or not. The aim of this study is to find out this question. 


\section{Induction}

\section{THEORETICAL BACKGROUND}

Inductive reasoning, or induction, makes generalizations from particular facts or instances. It is contrasted with deduction, the reasoning process which begins with a general to reach a specific, logical conclusion. [3]

\section{Inductive instruction}

According to [1], an instructor using an inductive method begins by exposing students to a particular case, or cases, of a concept. Then, students are encouraged to observe the samples, ask questions, or make generalizations from their observations. The role of the teacher is to create opportunities and contexts in which students can successfully make the appropriate generalizations, and to guide students as needed.

Prince (2006) described inductive instruction as follows:

The instruction begins with specifics - a set of observations or experimental data to interpret, a case study to analyze, or a complex real-world problem to solve. As the students attempt to analyze the data or scenario or solve the problem, they generate a need for facts, rules, procedures, and guiding principles, at which point they are either presented with the needed information or helped to discover it for themselves. [4]

\section{The process of inductive instruction}

Following steps are used while teaching by this method [5]:

(a) Presentation of examples. Teacher gives some examples as the particular cases of a new concept, or of a law.

(b) Observation. The students observe these examples and try to reach to some conclusion.

(c) Generalization. After observing the examples presented, the teacher and student decide some common formulae, principle or law by logical mutual discussion.

(d) Testing and verification. After deciding some common formula, principle or law, students test and verify the law by logical reasoning. Due to this process, children logically attain the new knowledge.

\section{Illustration}

Step 1: The teacher presents two particular exercises as follows:

Find $\mathrm{I}_{1}=\int \frac{\mathrm{d} x}{x \sqrt{x^{2}+1}} \quad$ and $\mathrm{I}_{2}=\int \frac{\mathrm{d} x}{x \sqrt{x^{2}+4}}$.

Brief solution

- Find $I_{1}$

Let $\mathrm{t}=\sqrt{x^{2}+1}$. We have: $\mathrm{I}_{1}=\int \frac{\mathrm{dt}}{\mathrm{t}^{2}-1}$

$I_{1}=-\frac{1}{2} \int\left(\frac{1}{t+1}-\frac{1}{t-1}\right) d t=-\frac{1}{2} \ln \left|\frac{t+1}{t-1}\right|+C$

Therefore, $\mathrm{I}_{1}=-\ln \left|\frac{1+\sqrt{x^{2}+1}}{x}\right|+\mathrm{C}$

- Find $\mathrm{I}_{2}=\int \frac{\mathrm{d} x}{x \sqrt{x^{2}+4}}$

We have: $\quad \mathrm{I}_{2}=\int \frac{x \mathrm{~d} x}{x^{2} \sqrt{x^{2}+4}}$

$$
\text { Let } \mathrm{t}=\sqrt{x^{2}+4} \Rightarrow \mathrm{I}_{2}=\int \frac{\mathrm{dt}}{\mathrm{t}^{2}-4}
$$

$I_{2}=-\frac{1}{4} \int\left(\frac{1}{t+2}-\frac{1}{t-2}\right) d t=-\frac{1}{4} \ln \left|\frac{t+2}{t-2}\right|+C=-\frac{1}{4} \ln \left|\frac{\sqrt{x^{2}+4}+2}{\sqrt{x^{2}+4}-2}\right|+C$

Therefore, $I_{2}=-\frac{1}{2} \ln \left|\frac{2+\sqrt{x^{2}+4}}{x}\right|+C$

Step 2: Students discuss and make generalization of the above two exercises as possible.

Step 3: The teacher and students get the general problem as follows: 


$$
\mathrm{I}=\int \frac{\mathrm{d} x}{x \sqrt{x^{2}+\mathrm{a}^{2}}}
$$

Step 4: Verify (*) and give algorithm for solving it.

Algorithm for finding I:

$$
\mathrm{I}=\int \frac{\mathrm{d} x}{x \sqrt{x^{2}+\mathrm{a}^{2}}}(a>0)
$$

Step 1: It is written as: $\mathrm{I}=\int \frac{x \mathrm{~d} x}{x^{2} \sqrt{x^{2}+\mathrm{a}^{2}}}$

Step 2: Let $\mathrm{t}=\sqrt{x^{2}+\mathrm{a}^{2}}$ or $\mathrm{t}^{2}=x^{2}+\mathrm{a}^{2} \Rightarrow x \mathrm{~d} x=\mathrm{tdt}$, we obtain: $\mathrm{I}=\int \frac{\mathrm{dt}}{\mathrm{t}^{2}-\mathrm{a}^{2}}$

Step 3: Therefore, $I=-\frac{1}{2 \mathrm{a}} \ln \left|\frac{\mathrm{t}+\mathrm{a}}{\mathrm{t}-\mathrm{a}}\right|+\mathrm{C}=-\frac{1}{\mathrm{a}} \ln \left|\frac{\mathrm{a}+\sqrt{x^{2}+\mathrm{a}^{2}}}{x}\right|+C$

\section{Questionnaire:}

\section{METHODOLOGY}

In order to understand the mathematics teachers' perception on using inductive instruction into teaching topic "Primitive and Integral" - Calculus 12, we used the following five questions:

Question 1: Theo thầy (cô) việc vận dụng suy luận qui nạp vào dạy toán có quan trọng hay không? (How important is the application of inductive instruction into teaching mathematics?)

\begin{tabular}{|l|l|l|l|l|}
\hline $\begin{array}{l}\text { Hoàn toàn không quan trọng } \\
\text { (Completely unimportant) }\end{array}$ & $\begin{array}{l}\text { Không quan trọng } \\
\text { (Unimportant) }\end{array}$ & $\begin{array}{l}\text { Bình thừ̀ng } \\
\text { (Normal) }\end{array}$ & $\begin{array}{l}\text { Quan trọng } \\
\text { (Important) }\end{array}$ & $\begin{array}{l}\text { Rất quan trọng } \\
\text { (Very important) }\end{array}$ \\
\hline
\end{tabular}

Question 2: Thầy (cô) có thường xuyên vận dụng suy luận qui nạp vào dạy học nội dung nguyên hàm và tích phân hay không? (How often have you applied inductive instruction to give lessons on "Primitive and Integral?)

\begin{tabular}{|l|l|l|l|l|}
\hline $\begin{array}{l}\text { Rất hiếm khi } \\
\text { (Very rarely) }\end{array}$ & $\begin{array}{l}\text { Hiếm } k h i \\
\text { (Rarely) }\end{array}$ & $\begin{array}{l}\text { Thỉnh thoảng } \\
\text { (Sometimes) }\end{array}$ & $\begin{array}{l}\text { Thưòng xuyên } \\
\text { (Regularly) }\end{array}$ & $\begin{array}{l}\text { Rất thưòng xuyên } \\
\text { (Very regularly) }\end{array}$ \\
\hline
\end{tabular}

Question 3: Theo thầy (cô) việc tạo tình huống cho HS khám phá khái niệm, định lý, công thức, qui tắc bằng con đường qui nạp có phải là cách tiếp cận tốt hay không? (Using inductive instruction to guide students to discover mathematics, is it good?

\begin{tabular}{|l|l|l|l|l|}
\hline $\begin{array}{l}\text { Hoàn toán không tốt } \\
\text { (Completely not good) }\end{array}$ & $\begin{array}{l}\text { Không tốt } \\
\text { (Not good) }\end{array}$ & $\begin{array}{l}\text { Bình thường } \\
\text { (Normal) }\end{array}$ & $\begin{array}{l}\text { Tốt } \\
\text { (Good) }\end{array}$ & $\begin{array}{l}\text { Rất tốt } \\
\text { (Very good) }\end{array}$ \\
\hline
\end{tabular}

Question 4: Việc lựa chọ̣ phưong pháp để dạy chương nguyên hàm và tích phân, thầy (cô) có ưu tiên sử dụng phương pháp qui nạp để phát huy tính tích cực của học sinh không? (In order to make students active in learning "Primitive and Integral", have you preferred to inductive instruction?)

\begin{tabular}{|l|l|l|l|l|}
\hline $\begin{array}{l}\text { Có ưu tiên (Very } \\
\text { not Preferred) }\end{array}$ & $\begin{array}{l}\text { Không có ưu tiên } \\
\text { (Not preferred) }\end{array}$ & $\begin{array}{l}\text { Bình thuờng } \\
\text { (Normal) }\end{array}$ & $\begin{array}{l}\text { Bình thưòng } \\
\text { (Preferred) }\end{array}$ & $\begin{array}{l}\text { Rất ưu tiên } \\
\text { (Very preferred) }\end{array}$ \\
\hline
\end{tabular}

Question 5: Khi dạy học nội dung nguyên hàm và tích phân thầy (cô) thường sử dụng phưong pháp dạy học nào sau đây? When teaching "Primitive and Integration", which teaching method have you often used?

\begin{tabular}{|l|l|l|l|l|}
\hline $\begin{array}{l}\text { Phát hiện và giải quyết vấn đề } \\
\text { (Problem posing \& problem } \\
\text { solving) }\end{array}$ & $\begin{array}{l}\text { Khám phá có huớng dẫn } \\
\text { (Guided discovery) }\end{array}$ & $\begin{array}{l}\text { Hợ tác } \\
\text { (Cooperative learning) }\end{array}$ & $\begin{array}{l}\text { Gợi mở, vấn đáp } \\
\text { (Converstion } \\
\text { heuristic) }\end{array}$ & $\begin{array}{l}\text { Suy luận qui nạp } \\
\text { (Inductive } \\
\text { instruction) }\end{array}$ \\
\hline
\end{tabular}

Participants: 40 mathematics teachers of high schools in Province "Dong Thap" - Vietnam. (see Table 2)

Table 2 : Teachers from 4 high schools of Dong Thap province

\begin{tabular}{|l|l|l|l|l|}
\hline School & $\begin{array}{l}\text { High School } \\
\text { Lap Vo II }\end{array}$ & $\begin{array}{l}\text { High School Thien } \\
\text { Ho Duong }\end{array}$ & $\begin{array}{l}\text { High School Tran } \\
\text { Quoc Toan }\end{array}$ & $\begin{array}{l}\text { High School Phu } \\
\text { Dien }\end{array}$ \\
\hline $\begin{array}{l}\text { The number of mathematics } \\
\text { teachers (N=40) }\end{array}$ & 13 & 8 & 10 & 9 \\
\hline
\end{tabular}




\section{RESULTS AND DISCUSSION}

1. The awareness of teachers about the use inductive reasoning to teaching mathematics

Table 3: The answers of teacher to the question 1

\begin{tabular}{|l|l|l|l|l|}
\hline Completely unimportant & Unimportant & Normal & Important & Very important \\
\hline $0(0 \%)$ & $5(12.5 \%)$ & $10(25 \%)$ & $20(50 \%)$ & $5(12.5 \%)$ \\
\hline
\end{tabular}

The survey showed that $20(50 \%)$ teachers believe that the use inductive instruction in mathematics are important, $5(12.5 \%)$ teachers said that applying inductive methods in teaching mathematic is very important, $5(12.5 \%)$ teachers said applying this approach into mathematics is not important, $10(25 \%)$ teachers think that it is normal. Through this, we see that the majority of teachers $(62.5 \%)$ rightly recognize the importance of applying induction in teaching mathematics. (see Table 3)

\section{The use of inductive reasoning to teaching Primitive and Integration - Calculus 12}

Table 4: The answers of teachers to the question 2

\begin{tabular}{|l|l|l|l|l|}
\hline Very rarely & Rarely & Sometimes & Regularly & Very regularly \\
\hline $3(7.5 \%)$ & $4(10 \%)$ & $27(67.5 \%)$ & $6(15 \%)$ & $0(0 \%)$ \\
\hline
\end{tabular}

Table 4 indicated that the majority of teachers $(85 \%)$ have not focused on the application of inductive instruction into teaching Primitive and Integral.

\section{The creation of situations for students exploring the concept, theorem, formula, rule by induction}

Table 5 : The answers of teachers to the question 3

\begin{tabular}{|l|l|l|l|l|}
\hline Completely not good & Not good & Normal & Good & Very good \\
\hline 0 & $4(10 \%)$ & $4(10 \%)$ & $30(75 \%)$ & $2(5 \%)$ \\
\hline
\end{tabular}

The results of the survey showed that $32(80 \%)$ teachers believe that creating situations for students exploring the concept, theorem, formula, rule by induction is good way. (see Table 5)

4. The selection of inductive method to teach Primitive and Integral for promoting positive student

Table 6: The answers of teachers to the question 4

\begin{tabular}{|l|l|l|l|l|}
\hline Very not Preferred & Not preferred & Normal & Preferred & Very preferred \\
\hline $2(5 \%)$ & $3(7.5 \%)$ & $20(50 \%)$ & $9(22.5 \%)$ & $6(15 \%)$ \\
\hline
\end{tabular}

Through the Table 6, we saw that many teachers have not preferred the choice of inductive instruction to teach Primitive and Integral (about $72.5 \%$ ).

5. The use of teaching method when teaching Primitive and Integral - Calculus 12

Table 7: The answers of teachers to the question 5

\begin{tabular}{|l|l|l|l|l|}
\hline $\begin{array}{l}\text { Problem posing \& } \\
\text { problem solving }\end{array}$ & Guided discovery & Cooperative learning & $\begin{array}{l}\text { Conversation _ } \\
\text { heuristic }\end{array}$ & Inductive instruction \\
\hline $8(20 \%)$ & $7(17.5 \%)$ & $4(10 \%)$ & $19(47.5 \%)$ & $2(5 \%)$ \\
\hline
\end{tabular}

From the results of the survey, we found that very few teachers $(5 \%)$ have used inductive instruction to teach Primitive and Integral - Analysis 12 (see Table 7).

\section{CONCLUSION}

The inductive instruction is an active teaching method. By this method, the teacher can offer opportunities for students to observe, to analyze, to predict, and to generalize from some particular instances. However, according to experiences of many teacher, if applying this method into teaching mathematics in general and into topic Primitive and Integral in particular, the teacher take much time to teach a content or a skill of mathematics and it seem to be not suitable for weak students. Therefore, although most teachers of mathematics teachers have recognized the strong points of this method, but in teaching the topic "Primitive and Integral" of Calculus 12 in Vietnam, they have not been preferred to apply inductive instruction into their job.

\section{REFERENCES}

[1]. Biology Success! Teaching Diverse Learners (C) 2005 National Institute - Landmark College: Using varied instructional techniques: inductive and deductive teaching approach

[2]. Hao, T.V. (2007). Giải Tích 12 (Calculus 12), Nhà xuất bản Giáo dục Việt Nam, Hà Nội (in Vietnamese).

[3]. Loc, N.P., Hung, N. V. (2016). Teaching "Integration by Parts" in Calculus 12: A Pedagogical ExperimentBased on the Inductive Instruction. Sch. Bull.; Vol-2, Iss-5 (May, 2016):276-281

[4]. Prince, M. J., \& Felder, R.M. (2006). Inductive teaching and learning methods: definitions, comparisons, and research bases. J. Engr. Education, 95(2), 123-138.

[5]. METHODS OF TEACHING MATHEMATICS: Module 1: Inductive Method http://thiyagumath.blogspot.com/2011/05/module-1-inductivemethod.htm 